\title{
KECERNAAN KALSIUM DAN FOSFOR RANSUM KOMPLIT BERBASIS TEBON JAGUNG PADA TERNAK SAPI PERANAKAN ONGOLE (PO)
}

\author{
Asuela A. Koluod, C. L. Kaunang, R. A. V. Tuturoong*, M. R. Waani \\ Fakultas Peternakan Universitas Sam Ratulangi Manado, 95115
}

\begin{abstract}
ABSTRAK
Penelitian ini bertujuan untuk mengetahui kecernaan kalsium (Ca) dan fosfor (P) sapi peranakan ongole (PO) yang berbasis tebon jagung. Penelitian ini menggunakan 14 ekor sapi PO berumur $1,5-2$ tahun dengan berat $180-250 \mathrm{~kg}$. Penelitian ini menggunakan metode eksperimen, analisis yang digunakan adalah Uji T (keragaman yang tidak sama) yang terdiri dari 2 perlakuan 7 ulangan. Perlakuan yang digunakan adalah : $\mathrm{Ra}=50 \%$ konsentrat $+50 \%$ tebon jagung, $\mathrm{Rb}=50 \%$ konsentrat + $25 \%$ rumput raja $+25 \%$ tebon jagung. Variabel yang diamati adalah konsumsi $\mathrm{Ca}$, konsumsi $\mathrm{P}$, kecernaan $\mathrm{Ca}$ dan kecernaan P. Hasil analisis Uji $\mathrm{T}$ menunjukkan bahwa konsumsi $\mathrm{Ca}$ berbeda nyata $(\mathrm{P}<0,05)$ antara perlakuan $\mathrm{Ra}$ 31,49 gram/ekor/hari dan $\mathrm{Rb} 31,02$ gram/ekor/hari sedangkan kecernaan $\mathrm{Ca}$ perlakuan $\mathrm{Rb}(84,92 \%$ nyata lebih tinggi $(\mathrm{P}<0,01)$ dibanding $\mathrm{Ra}(77,70 \%)$. Hasil analisis Uji $\mathrm{T}$ menunjukkan bahwa konsumsi $\mathrm{P}$ perlakuan $\mathrm{Rb} 31,45$ gram/ekor/hari berbeda sangat nyata $(\mathrm{P}<0,01)$ dibanding $\mathrm{Ra} 30,52$ gram/ekor/hari dan kecernaan $\mathrm{P}$ perlakuan $\mathrm{Rb}$ $88,39 \%$ berbeda sangat nyata $(\mathrm{P}<0,01)$ dibanding $\mathrm{Ra} 83,94 \%$. Berdasarkan hasil penelitian ini dapat disimpulkan bahwa pemberian ransum komplit yang terdiri dari $50 \%$ konsentrat, $25 \%$ rumput raja (Pennisetum purpupoides) dan $25 \%$ tebon jagung meningkatkan kecernaan kalsium dan fosfor pada sapi PO.
\end{abstract}

Kata Kunci : Sapi PO, ransum komplit, kecernaan, kalsium, fosfor.

*Kosepondensi (corresponding author)

Email : ronny.tuturoong@yahoo.com

\section{ABSTRACT}

DIGESTIBILITY OF CALCIUM AND PHOSPHORUS COMPLETE FEED BASED ON CORN FORAGE IN ONGOLE CROSSBREED COWS. Research was conducted to evaluate digestibility of calcium and phoshorus ongole crossbreed cows based on Corn Forage. Fourteen cows were used in this experiment, one and a half to two years old by weight of one hundred eighty to two hundred and fifty kilograms. this research was using experimental method, the data were analyzed by $\mathrm{T}$ test (Unequal Variance Assumed). Consisting of two replications and seven treatments used. The treatment used was : $\mathrm{Ra}=$ $50 \%$ concentrate $+50 \%$ corn forage, $\mathrm{Rb}=50 \%$ concentrate+ $25 \%$ king grass $+25 \%$ corn forage. The variables measured were feed calcium and phosphorus consumption, calcium and phosphorus digestibility. The results of analysis $\mathrm{T}$ test showed that intake capacity of calcium significantly affected $(\mathrm{P}<0.05)$ between $\mathrm{Ra}$ (31.49 gram/animal/day) and $\mathrm{Rb}$ (31.02 gram/animal/day) while calcium digestibility of treatment $\mathrm{Rb}(84.92 \%)$ higher significantly than $\mathrm{Ra}(77.70 \%)$. The results of analysis $\mathrm{T}$ test showed that intake capacity of phosphorus $\mathrm{Rb}$ (31.45 gram/animal/day) significantly affected $(\mathrm{P}<0.01)$ than $\mathrm{Ra}(30.52$ gram/animal/day) and phosphorus digestibility $\mathrm{Rb}(88.39 \%)$ significantly affected $(\mathrm{P}<0.01)$ than Ra (83.94\%). Based on the research result can be concluded that the complete feed consisting of $50 \%$ concentrate, $25 \%$ king grass (Pennisetum purpupoides) dan $25 \%$ corn forage increase digestibility of calcium and phosphorus ongole crossbreed cows. 
Key Words: Ongole crossbreed cattle, complete feed, digestibility, calcium and phosphorus.

\section{PENDAHULUAN}

Seiring dengan meningkatnya jumlah penduduk, tingkat kesejahteraan dan tingkat pendidikan, kebutuhan daging masyarakat juga semakin meningkat. Ruminansia merupakan pasokan daging terbesar untuk kebutuhan manusia. Tingkat permintaan daging sapi akan meningkat ketika populasi manusia meningkat (Tuturoong et al., 2013). Sapi potong merupakan salah satu sumber penghasil daging yang potensial, memiliki nilai gizi tinggi dan sangat bermanfaat bagi masyarakat. Keberhasilan usaha penggemukan ternak sapi potong dapat dicapai melalui manajemen pemeliharaan yang baik antara lain manajemen pakan.

Pakan memiliki peranan penting bagi ternak untuk pertumbuhan dan menghasilkan produk hewani. Dalam suatu usaha peternakan pakan memiliki kontribusi yang paling tinggi yaitu sekitar $60-70 \%$, karena pakan merupakan sumber utama energi bagi ternak. Pakan sapi umumnya terdiri dari hijauan dan konsentrat. Hijauan pakan sapi yang diberikan masih belum memenuhi kebutuhan ternak, sehingga perlu adanya penambahan konsentrat. Rumput raja
(Pennisetum purpupoides) dan tebon jagung merupakan hijauan yang sering diberikan pada sapi potong.

Produksi rumput raja cukup tinggi dibandingkan dengan rumput lainnya yaitu 200-250 Ton/ha/tahun (Nasriya et al., 2016) dengan kandungan nutrisi bahan kering (BK) 21,21\%, total digestible nutient (TDN) 53,89\%, serat kasar (SK) 25,48\%, protein kasar (PK) 11,68\%, kalsium (Ca) $0,37 \%$ dan fosfor (P) $0,39 \%$ (Rumiyati, 2008). Tebon jagung adalah seluruh tanaman jagung termasuk batang, daun dan buah jagung muda yang umumnya dipanen pada umur tanaman 4565 hari dengan kandungan nutrisi tebon jagung yaitu, PK 12,06\%, SK 25,2\%, Ca 0,28\%, P 0,23\% (Erna dan Sarjiman, 2007). Konsentrat atau bahan pakan penguat adalah pakan berkonsentrasi tinggi yang mengandung protein kasar dan energi yang cukup dengan kadar serat kasar yang relatif rendah dan mudah dicerna. Fungsi konsentrat ini adalah memperkaya nilai gizi pada bahan pakan lain yang nilai gizinya rendah.

Kalsium berperan penting untuk menyokong struktur dan kekokohan tulang dan gigi. kalsium paling banyak diserap oleh usus halus, terutama pada bagian duodenum dan jejunum. Dalam hijauan pakan umumnya Ca terikat dalam kalsiumoksalat (Ward dan Herber, 1982) bahkan dalam dinding sel (McManus et al., 1979) 
sehingga sulit untuk dicerna. Penyerapan $\mathrm{Ca}$ dapat melalui transport aktif maupun transport pasif atau difusi. Penyerapan $\mathrm{Ca}$ melalui usus hewan disesuaikan dengan kebutuhan, sebagai contoh, sapi yang berusia muda dengan kebutuhan $\mathrm{Ca}$ tinggi akan menyerap $\mathrm{Ca}$ lebih banyak dibandingkan dengan sapi yang lebih tua dengan kebutuhan yang lebih sedikit. Penyerapan $\mathrm{Ca}$ bergantung pada kelarutannya dan hubungan dengan membran absorpsi. Daya larut dan penyerapan $\mathrm{Ca}$ juga dipengaruhi oleh keadaan $\mathrm{pH}$ pada usus halus. Kebutuhan nutrien dipengaruhi oleh beberapa hal antara lain tingkat pertumbuhan, ukuran tubuh ternak, lingkungan, keturunan, penyakit, parasit, jenis ternak, ketidakserasian nutrien dan kekurangan nutrient (Umiyasih dan Anggraeny, 2007).

Mineral $\mathrm{P}$ diserap dari makanan dalam bentuk $\mathrm{P}$ anorganik bebas setelah mengalami hidrolisis di dalam saluran pencernaan. Proses penyerapan P di dalam usus dapat melalui proses difusi atau transport aktif. Penyerapan aktif P melewati sel usus tergantung pada pertukaran dengan ion natrium. Pembuangan $\mathrm{P}$ terutama Sekitar $80-85 \%$ terdapat dalam tulang dan 15 - 20\% berada dalam jaringan lunak dan cairan (Greisert et al., 2010).

Konsumsi pakan merupakan sejumlah pakan yang dapat dikonsumsi ternak pada periode waktu tertentu, merupakan faktor penting yang menetukan fungsi dan respon ternak serta penggunaan nutrien yang ada dalam pakan. Jumlah konsumsi pakan merupakan salah satu tanda terbaik dari produktivitas ternak dan juga faktor esensial yang menjadi dasar untuk hidup dan menentukan produksi. Tinggi rendahnya konsumsi pakan sangat dipengaruhi oleh faktor-faktor eksternal (lingkungan), faktor internal (kondisi ternak itu sendiri) dan pakan yang diberikan (Parakkasi, 1999).

Nilai kualitas suatu bahan pakan dapat diketahui melalui percobaan kecernaan pada ternak. Kecernaan bahan pakan sangat tergantung berbagai faktor, antara lain konsumsi pakan, associative effect, pemrosesan pakan, kedewasaan (umur) hijauan, dan suhu lingkungan (Astuti et al., 2009). Kecernaan in vivo mengukur kecernaan pada ternak dengan melihat selisi antara konsumsi dan feses dengan pemahaman bahwa apa yang dikeluarkan oleh ternak melalui feses tidak dicerna (Tuwaidan et al., 2015). Penelitian ini bertujuan untuk mengetahui pengaruh tebon jagung dalam ransum komplit terhadap kecernaan $\mathrm{Ca}$ dan $\mathrm{P}$ pada ternak sapi PO.

\section{MATERI DAN METODE PENELITIAN}


Penelitian ini dilaksanakan di UPTD Balai Benih Ternak Desa Tampusu Kecamatan Remboken. Penelitian ini menggunakan 14 ekor sapi PO dengan umur 1,5-2 tahun dan bobot badan 180-250 kg. Kandang yang digunakan adalah kandang individu sebanyak 14 kandang yang dilengkapi dengan tempat pakan dan minum. Perlengkapan lain yang digunakan dalam penelitian ini yaitu timbangan, kantong plastik, alat tulis menulis, sekop dan chopper. Pakan yang digunakan meliputi konsentrat yang terdiri dari : jagung, dedak halus, tepung kedelai, tepung ikan, bungkil kelapa, premix (suplemen, vitamin, mineral) dan garam, tebon jagung dan rumput raja (Pennisetum purpupoides). Penelitian ini menggunakan metode eksperimen dengan menggunakan analisis Uji T (keragaman tidak sama) (Snedecor and Cochran, 1989; Derrick, et al. 2017) yang terdiri dari 2 perlakuan dan 7 ulangan, perlakuan yang di terapkan adalah:

$\mathrm{Ra}=50 \%$ konsentrat $+50 \%$ tebon jagung $\mathrm{Rb}=50 \%$ konsentrat $+25 \%$ rumput raja + $25 \%$ Tebon Jagung

Perlakuan percobaan dapat dilihat pada Tabel 2, sementara kompisisi nutrien setiap perlakuan dapat dilihat pada Tabel 3 . Kandungan nutrien yang digunakan untuk percobaan ini tercantum pada Tabel 1.

\section{Tatalaksana Penelitian}

Pelaksanaan penelitian ini dibagi menjadi 3 tahap yaitu tahap pendahuluan, tahap pra koleksi dan tahap koleksi.

\section{Tahap Pendahuluan}

Pada awal penelitian ternak diberikan kesempatan untuk beradaptasi dengan pakan perlakuan. Adaptasi pakan dilakukan selama 7 hari. Adaptasi dilakukan dengan tujuan untuk membiasakan ternak mengkonsumsi pakan perlakuan dan mengetahui konsumsi pakan bebasnya, dimana dilakukan pengambilan dan konsumsi. Pakan diberikan secara ad libitum serta air minum disediakan setiap saat. Sebelum diberikan ke ternak, tebon jagung dan rumput raja dicacah (Chopper) terlebih dahulu dengan ukuran $\pm 5 \mathrm{~cm}$. Konsumsi ternak dihitung dari konsumsi bahan kering.

\section{Tahap Pra-Koleksi}

Dua hari sebelum pengambilan dan koleksi, dilakukan pembatasan pemberian pakan sebanyak $80 \%$ dari rataan konsumsi pakan pada tahap pendahuluan. Pembatasan pakan dilakukan agar pakan yang diberikan dapat dikonsumsi secara keseluruhan dan tidak tersisa.

\section{Tahap Koleksi}

Pada tahap ini, pakan tetap diberikan sebanyak $80 \%$. Feses ditimbang setiap defikasi dan diambil sampel 5\% untuk analisis. Pengumpulan feses dilakukan selama 5 hari begitu juga dengan 
Tabel 1. Komposisi zat-zat makanan pakan percobaan

\begin{tabular}{lccc}
\hline \multirow{2}{*}{ Nutrien } & Konsentrat & Tebon Jagung*) & Rumput Raja **) \\
\cline { 2 - 4 } & \multicolumn{3}{c}{$\%$} \\
\hline Bahan Kering & 87,93 & 19,73 & 20,30 \\
Protein & 16,65 & 10,90 & 9,52 \\
Lemak Kasar & 10,75 & 2,17 & 3,14 \\
Serat Kasar & 11,23 & 33,21 & 31,26 \\
NDF & 27,23 & 69,81 & 73,52 \\
ADF & 14,39 & 40,20 & 44,49 \\
Ca & 0,73 & 0,39 & 0,35 \\
P & 0,82 & 0,23 & 0,28 \\
Abu & 9,11 & 7,67 & 9,38 \\
BETN & 40,48 & 46,05 & 44,98 \\
Energi Bruto (Kkal) & 3708,89 & 3791,00 & 3375,00 \\
\hline
\end{tabular}

*) Menurut Tulung et al. (2020)

**) Hasil Lab. Nutrisi dan Makanan Ternak Fak. Peternakan UB (2019)

Tabel 2. Susunan ransum percobaan

\begin{tabular}{lcc}
\hline \multirow{2}{*}{ Bahan Pakan } & \multicolumn{2}{c}{ Perlakuan } \\
\cline { 2 - 3 } & $\mathrm{Ra}$ & $\mathrm{Rb}$ \\
\hline Konsentrat & 50 & 50 \\
Rumput Raja & 0 & 25 \\
Tebon Jagung & 50 & 25 \\
\hline Total & 100 & 100 \\
\hline
\end{tabular}

Tabel 3. Komposisi zat nutrien dan energi bruto ransum perlakuan

\begin{tabular}{lcc}
\hline \multirow{2}{*}{ Nutrien } & \multicolumn{2}{c}{ Perlakuan } \\
\cline { 2 - 3 } & $\mathrm{Ra}$ & $\mathrm{Rb}$ \\
\hline Protein Kasar & 13,77 & 13,43 \\
$\mathrm{NDF}$ & 48,52 & 49,44 \\
$\mathrm{ADF}$ & 27,29 & 28,36 \\
$\mathrm{Ca}$ & 0,56 & 0,55 \\
$\mathrm{P}$ & 0.52 & 0,54 \\
\hline
\end{tabular}

Keterangan: Dihitung berdasarkan Tabel 1.

pengambilan sampel pakan. Pada periode ini diambil sampel pakan dan feses. Sampel pakan dan feses akan dianalisis di laboratorium.

\section{Variabel yang Diamati}

- Konsumsi Ca : Diperoleh dari selisih antara Ca dalam pakan yang diberikan dengan Ca dalam pakan sisa. 
- Konsumsi P : Diperoleh dari selisih antara $\mathrm{P}$ dalam pakan yang diberikan dengan $\mathrm{P}$ dalam pakan sisa.

- Kecernaan $\mathrm{Ca}=$ $\frac{\text { Konsumsi Ca }- \text { Ca Feses }}{\text { Konsumsi Ca }} \times 100 \%$

- Kecernaan $\mathrm{P}=$ $\frac{\text { Konsumsi P }-\mathrm{P} \text { Feses }}{\text { Konsumsi P }} \times 100 \%$

\section{HASIL DAN PEMBAHASAN}

Data hasil penelitian tentang pemberian ransum komplit berbasis tebon jagung terhadap konsumsi dan kecernaan Ca dan P pada sapi PO dapat dilihat pada Tabel 4.

\section{Konsumsi kalsium (Ca) sapi PO}

Rataan konsumsi Ca pada Tabel 4 memperlihatkan bahwa konsumsi Ca pada perlakuan Ra sebesar 31,49 g/ekor/hari dan konsumsi $\mathrm{Ca}$ pada perlakuan $\mathrm{Rb}$ sebesar 31,02 g/ekor/hari. Hasil analisis Uji T menunjukkan bahwa perlakuan memberikan pengaruh yang berbeda nyata
$(\mathrm{P}<0,05)$ terhadap konsumsi $\mathrm{Ca}$ pada sapi PO. Konsumsi $\mathrm{Ca}$ pada $\mathrm{Ra}$ lebih tinggi dibanding $\mathrm{Rb}$ disebabkan kandungan $\mathrm{Ca}$ pada tebon jagung lebih tinggi dari rumput raja (Tabel 1), walaupun konsumsi BK pada $\mathrm{Ra} 74,43$ g/ekor/hari lebih rendah dibandingkan $\mathrm{Rb}$ 79,82 g/ekor/hari. Jumlah konsumsi nutrien pada ternak dipengaruhi oleh kandungan nutrien tersebut dalam pakan. Menurut Tilman et al. (1992) konsumsi pakan tergantung pada kandungan dinding sel pakan tersebut. Pada Tabel 3 dapat dilihat bahwa kandungan dinding sel (NDF) pada $\mathrm{Rb} 49,44 \%$ lebih tinggi dibanding NDF pada $\mathrm{Ra} 48,52 \%$ menyebabkan konsumsi Ra lebih tinggi dari Rb. Selanjutnya Tilman et al. (1992) menyatakan bahwa hijauan dengan kandungan dinding sel yang tinggi mempunyai palatabilitas rendah sehingga konsumsi pakannya lebih rendah dibanding dengan hijauan yang kandungan dinding selnya rendah. Makin tinggi kandungan dinding sel suatu pakan maka akan semakin

Tabel 4. Nilai rataan konsumsi dan kecernaan kalsium $(\mathrm{Ca})$ dan fosfor $(\mathrm{P})$ ransum komplit berbasis tebon jagung pada ternak sapi PO

\begin{tabular}{lcc}
\hline \multirow{2}{*}{ Parameter } & \multicolumn{2}{c}{ Perlakuan } \\
\cline { 2 - 3 } & $\mathrm{Ra}$ & $\mathrm{Rb}$ \\
\hline Konsumsi Ca (gram/ekor/hari) & $31,49^{\mathrm{a}}$ & $31,02^{\mathrm{b}}$ \\
Konsumsi P (gram/ekor/hari) & $30,52^{\mathrm{a}}$ & $31,45^{\mathrm{b}}$ \\
Kecernaan Ca (\%) & $77,70^{\mathrm{a}}$ & $84,92^{\mathrm{b}}$ \\
Kecernaan P (\%) & $83,94^{\mathrm{a}}$ & $88,39^{\mathrm{b}}$ \\
\hline
\end{tabular}

Keterangan: Superskrip yang berbeda pada baris yang sama menunjukkan perbedaan yang sangat nyata $(\mathrm{P}<0,01)$ 
besar ketahanannya terhadap degradasi mikroba, sehingga waktu tinggal partikel akan lebih lama, terutama partikel yang tidak tercerna, hal ini akan menurunkan konsumsi pakan (Hadi et al., 2011).

\section{Konsumsi fosfor (P) sapi PO}

Rataan konsumsi P pada Tabel 4 memperlihatkan bahwa konsumsi $\mathrm{P}$ pada perlakuan Ra sebesar 30,52 g/ekor/hari dan konsumsi $\mathrm{P}$ pada perlakuan $\mathrm{Rb}$ sebesar 31,45 g/ekor/hari. Hasil analisis Uji T menunjukkan bahwa perlakuan memberikan perbedaan yang sangat nyata $(\mathrm{P}<0,01)$ terhadap konsumsi P. Konsumsi $\mathrm{P}$ pada $\mathrm{Rb}$ lebih tinggi dibanding $\mathrm{Ra}$ dikarenakan kandungan $\mathrm{P}$ pada $\mathrm{Rb} 0,54 \%$ lebih tinggi dibandingkan Ra 0,52\% dapat dilihat pada Tabel 3, dan sejalan dengan konsumsi BK dimana konsumsi Rb 79,82 g/ekor/hari lebih tinggi dibanding Ra 74,43 g/ekor/hari. Konsumsi $\mathrm{P}$ pada $\mathrm{Rb}$ lebih tinggi dibanding Ra juga disebabkan oleh kecernaan $\mathrm{P}$ yang lebih tinggi pada $\mathrm{Rb}$ dibanding $\mathrm{Ra}$, dapat dilihat pada nilai kecernaan pada Tabel 4. Menurut Arora (1983), konsumsi pakan dipengaruhi oleh laju pencernaan pakan dan tergantung pada bobot badan ternak dan kualitas pakan.

\section{Kecernaan kalsium (Ca) pada sapi PO}

Hasil analisis menunjukkan bahwa rataan kecernaan Ca perlakuan $\mathrm{Rb} 84,92 \%$ berbeda sangat nyata $(\mathrm{P}<0,01)$ terhadap kecernaan Ca pada perlakuan Ra 77,70\%. Konsumsi Ca pada $\mathrm{Rb}$ 31,02 g/ekor/hari lebih rendah dibanding $\mathrm{Ra} 31,49$ g/ekor/hari menyebabkan kecernaan $\mathrm{Ca}$ pada $\mathrm{Rb}$ nyata lebih tinggi sehingga meningkatkan penyerapan. Parakkasi (1999) menyatakan bahwa penyerapan $\mathrm{Ca}$ lebih banyak bila hewan mengkonsumsi sedikit $\mathrm{Ca}$ sebaliknya bila konsumsi $\mathrm{Ca}$ sedang dan banyak penyerapan akan menurun. Penelitian ini menunjukkan adanya efek asosiatif, menurut Tuturoong et al. (2014), daya cerna campuran bahan pakan tidak selalu sama dengan rata-rata daya cerna komponen bahan-bahan yang menyusunnya, hal ini disebabkan adanya efek asosiasi pakan. Penyerapan $\mathrm{Ca}$ bergantung pada kelarutannya dan hubungan dengan membran absorpsi. Daya larut dan penyerapan $\mathrm{Ca}$ juga dipengaruhi oleh keadaan pH pada usus halus (Nurlena, 2005).

\section{Kecernaan Fosfor (P) pada Sapi PO}

Hasil analisis menunjukkan bahwa rataan kecernaan $\mathrm{P}$ pada perlakuan $\mathrm{Rb}$ $88,39 \%$ berbeda sangat nyata $(\mathrm{P}<0,01)$ dibanding dengan kecernaan $P$ pada perlakuan Ra 83,94\%. Kecernaan P pada $\mathrm{Rb}$ lebih tinggi dibanding Ra. Pada Tabel 1, 
kandungan $\mathrm{P}$ pada rumput raja lebih tinggi dibanding dengan kandungan $\mathrm{P}$ pada tebon jagung. Hal ini yang memungkinkan bahwa kecernaan $\mathrm{P}$ pada perlakuan $\mathrm{Rb}$ lebih tinggi dari kecernaan $\mathrm{P}$ pada perlakuan $\mathrm{Ra}$. Diduga bahwa mineral $\mathrm{P}$ pada rumput raja lebih banyak terdistribusi pada isi sel yang akan lebih mudah dilepas daripada di dinding sel bahan pakan. Suhada et al. (2012) salah satu faktor yang mempengaruhi ketersediaan mineral adalah distribusi mineral dalam sel tanaman. Kecernaan $\mathrm{P}$ pada penelitian ini lebih tinggi dibanding penelitian Alfian (2014) yang melaporkan kecernaan $\mathrm{P}$ ransum pada ternak kambing yang diberi rumput raja berkirsar 46,22\% - 79,83\%, hal ini mungkin disebabkan oleh perbedaan jenis ternak yang digunakan dan komposisi pakan perlakuan. Penyerapan $\mathrm{P}$ dipengaruhi oleh sumber $\mathrm{P}$ dalam pakan, $\mathrm{pH}$ pada usus, umur hewan, parasit pada saluran pencernaan, dan asupan beberapa mineral lain seperti Ca, Fe, Mn, K, dan Mg (Nurlena, 2005).

\section{KESIMPULAN}

Berdasarkan hasil penelitian ini dapat disimpulkan bahwa pemberian ransum komplit yang terdiri dari 50\% konsentrat, 25\% Rumput Raja (Pennisetum purpupoides) dan 25\% Tebon Jagung meningkatkan kecernaan Kalsium dan Fosfor pada sapi PO.

\section{DAFTAR PUSTAKA}

Alfian, B. 2014. Konsunsi dan Kecernaan Mineral Pada Kambing Bligon yang Diberi Pakan Hijauan Berbasis Rumput Raja. Tesis. Universitas Gajah Mada, Yogyakarta

Arora, S.P. 1983. Microbial Digestion in Ruminants. India Council Agricultural Research.New Delhi.

Astuti, A., A. Agus, S. P. S. Budhi. 2009. Pengaruh penggunaan high quality feed supplement terhadap konsumsi dan kecernaan nutrien sapi perah awal laktasi. Buletin Peternakan 33(2): 81-87.

Derrick, B., B. Russ, D. Toher, dan P. White. 2017. Test statistics for the comparison of means for two samples that include both paired and independent observations. J. Modern Applied Statistical Methods 16(1): 137-157.

Erna, W. dan Sarjiman, 2007. Budidaya hijauan pakan bersama tanaman pangan sebagai upaya penyediaan hijauan pakan di lahan sempit. Jurnal Peternakan dan Lingkungan 7: $134-141$

Greisert, B.G., G.E. Erickson, T.J. Klopfeinstein, C.N. Macken, M.K. Luebbe, dan J.C. McDonald. 2010. Phosporous requirement and excretion of finishing beef cattle feed different concentrations of phosporous. J. Anim. Sci. 88: 2393 -2402 .

Hadi, R. F., Kustantinah, dan H. Hartadi. 2011. Kecernaan in sacco hijauan leguminosa dan hijauan non leguminosa dalam rumen sapi peranakan ongole. Buletin Peternakan 35(2): $79-85$. 
Mc Manus, W.R., R.G. Antony, L.L. Grout, AS. Malin, dan V.N.E. Robinson. 1979. Biocristallization of mineral material on forage plant cell walls. Aust. J. Agric. Res. 30: 635-649.

Nasriya, R.A.V. Tuturoong, C.L. Kaunang, S.S. Malalantang, M.M. Tindangen 2016. Pengaruh pemberian rumput raja (Pennisetum Purpupoides) dan tebon jagung terhadap kecernaan bahan kering dan bahan organik pada sapi PO pedet jantan. Zootec 36(2): 387-394.

Nurlena. 2005. Tampilan Kalsium dan Fosfor Darah, Produksi Susu, Ion kalium, dan Jumlah bakteri Susu Sapi Perah Friesian Holstein Akibat Pemeberian Aras Sauropus androgynus (L) Merr (KATU). Tesis. Program Pascasarjana. Universitas Diponegoro Semarang.

Parakkasi. A. 1999. Ilmu Nutrisi dan Makanan Ternak Ruminan. UI Press. Jakarta.

Rumiyati. 2008. Pengaruh imbangan jerami kacang tanah dengan rumput raja dalam ransum terhadap performan sapi PFH jantan. Skripsi. Fakultas Pertanian UNS, Solo

Snedecor, G.W. dan W.G. Cochran. 1989. Statistical Methods, Eighth Edition, Iowa State University Press.

Suhada, A. T., E. Pangestu dan L. K. Nuswantara. 2012. Kelarutan mineral $\mathrm{Ca}$ dan $\mathrm{Zn}$ hasil samping agroindustri pada rumen kambing Jawarandu secara in sacco. J. Anim Agriculture 1(1): 757-775.

Tilman, A. D., S. Reksohadiprodjo, H. Hartadi, S. Prawirokusumo, dan S. Lebdoseokojo. 1998. Ilmu Makanan Ternak Dasar. Cetakan Ke- 6, Gadjah Mada University Press, Yogyakarta.
Tulung, Y.L.R., A.F. Pendong, B. Tulung. 2020. Evaluasi nilai biologis pakan lengkap berbasis tebon jagung dan rumput campuran terhadap kinerja produksi Sapi Peranakan Ongole (PO). Zootec 40(1): 363 - 379.

Tuturoong, R.A.V., Hartutik, Soebarinoto, Ch. Kaunang. 2013. Nutrition evaluation in vitro. of ammoniated benggala grass and fermented sago waste. J. Scintific Paper D. Vol. LVI:

Tuturoong, R.A.V., Hartutik, Soebarinoto, Ch. Kaunang. 2014. Evaluasi Nilai Nutrisi Rumput Benggala Teramoniasi dan Ampas Sagu Terfermentasi Dalam Pakan Komplit Terhadap Penampilan Kambing Kacang. Disertasi. Fakultas Peternakan Universitas Brawijaya. Malang

Tuwaidan, N.W.H., M.R. Waani, S.S. Malalantang. 2015. Konsumsi dan kecernaan jerami jagung manado kuning dan jerami jagung hibrida jaya 3 pada sapi PO. Zootec 35(2): 328-334.

Umiyasih, U. dan Y.N. Anggraeny. 2007. Petunjuk Teknis Ransum Seimbang, Strategi Pakan pada Sapi Potong. Laporan Penelitian, Pusat Penelitian dan Pengembangan Pertanian dan Peternakan, Departemen Pertanian. Jakarta

Ward, G. dan L.H. Harbers. 1982. Effect of $\mathrm{pH}$ on extractibility of calcium and oxalate from alfafa leafs. J. Dairy Sci. 65: 154-160. 